\title{
A Lesson to Learn in an latrogenic Perforation of Sigmoid Volvulus after Endoscopic Derotation
}

\author{
Endoskopik Derotasyon Sonrası Sigmoid Volvulusun İyatrojenik Perforasyonundan Alınacak Bir Ders
}

\author{
Pauline Yap ${ }^{1}$, Firdaus Hayati ${ }^{1}$, Nik Amin Sahid ${ }^{1}$, Nornazirah Azizan², Fairrul Kadir ${ }^{3}$, Andee Dzulkarnaen Zakaria ${ }^{4}$ \\ Nik Qisti Fathi ${ }^{5}$
}

${ }^{1}$ Department of Surgery, Faculty of Medicine and Health Sciences, Universiti Malaysia Sabah, Kota Kinabalu, Sabah, Malaysia

${ }^{2}$ Department of Pathobiology and Medical Diagnostic, Faculty of Medicine and Health Sciences, Universiti Malaysia Sabah, Kota Kinabalu, Sabah, Malaysia

${ }^{3}$ Department of Medicine, Faculty of Medicine and Health Sciences, Universiti Malaysia Sabah, Kota Kinabalu, Sabah, Malaysia

${ }^{4}$ Department of Surgery, Faculty of Medicine, Universiti Sains Malaysia, Kota Bharu, Kelantan, Malaysia

${ }^{5}$ Department of Surgery, Faculty of Medicine and Health Sciences, Universiti Putra Malaysia, Serdang, Selangor, Malaysia

\section{ABSTRACT}

A 78-year-old gentleman was diagnosed with stable sigmoid volvulus after complaining of acute abdominal pain with no bowel opening for a week. Abdominal radiography confirmed the diagnosis after showing a typical coffee bean sign. Opting for conservative management, an urgent endoscopic reduction was attempted with insertion of flatus tube and achieved successfully. However, the flatus tube dislodged in the ward and reinsertion was attempted without direct vision. Patient's condition deteriorated and computed tomography of the abdomen revealed an extensive pneumoperitoneum requiring urgent laparotomy. Massive faecal contamination was visualized with evidence of a sharp tip of the flatus tube piercing through the sigmoid colonic wall. Hartmann's procedure was performed. However, he deteriorated despite the surgery. He succumbed 3 days after the operation. We describe a case of a successful endoscopic derotation of sigmoid volvulus with iatrogenic bowel perforation after reinsertion of flatus tube.

Key Words: Sigmoid colon, volvulus, colonoscopic surgical procedure, iatrogenic disease

Received: 11.09 .2018

Accepted: 03.02.2019

\section{ÖZET}

Yetmiş sekiz yaşında bir erkek, bir hafta boyunca bağırsak açıklı̆̆ı olmayan akut karın ağrısı şikayeti sonrasında stabil sigmoid volvulus tanısı aldı. Abdominal radyografi tipik bir kahve çekirdeği işareti gösterdikten sonra tanıyı doğruladı. Konservatif yönetimi tercih ederek, flatus tüpün yerleştirilmesiyle acil endoskopik redüksiyon girişimi başarılı bir şekilde uygulandı. Ancak, flatus tüpü serviste yerinden oynamış ve doğrudan görüş olmadan yeniden yerleştirmeye çalışılışıı. Hastanın durumu kötüleşti ve batın bilgisayarlı tomografisinde acil laparotomi gerektiren geniş bir pnömoperiton olduğu ortaya çıktı. Masif fekal kontaminasyon, flatus tüpünün keskin ucunun sigmoid kolonu duvarı boyunca deldiği kanıtı ile görselleştirildi. Hartmann prosedürü yapıldı. Ancak ameliyat olmasına rağmen hastanın durumu kötüleşti. Operasyondan 3 gün sonra kaybedildi. Flatus tüpünün tekrar yerleştirilmesinden sonra oluşan iyatrojenik bağırsak perforasyonu ile birlikte sigmoid volvulusun başarıı endoskopik derotasyonunu tanımladık.

Anahtar Sözcükler: Sigmoid kolon, volvulus, kolonoskopik cerrahi prosedür, iyatrojenik hastalık

Geliş Tarihi: 09.11.2018

Kabul Tarihi: 02.03.2019

\section{INTRODUCTION}

Acute sigmoid volvulus is a surgical emergency. It is defined as torsion of the sigmoid colon around its mesenteric axis leading to an acute large intestinal obstruction. If it's left untreated, often it results in life-threatening complications namely bowel ischemia, gangrene, and perforation(1,2). The current primary treatment for uncomplicated and stable sigmoid volvulus in emergency setting is colonoscopic derotation and decompression via flatus tube(3). Emergency surgery is required in patients who had failed nonoperative treatment or in those with peritonitis, perforation or bowel gangrene upon initial assessment(4). One of the most common complications of sigmoid volvulus is sigmoid perforation. However, iatrogenic sigmoid perforation post-endoscopic derotation due to inappropriately placed flatus tube has not been reported before. We describe a 78-year-old gentleman who had a successful endoscopic derotation of sigmoid volvulus, developed bowel perforation after reinsertion of flatus tube and discuss its literature review. To the best of our knowledge, there was no other published case report similar to this case.

\section{CASE REPORT}

A 78-year-old gentleman was admitted to our hospital with abdominal distension and a 7 days history of no bowel opening associated with nausea and vomiting of partially digested food. He has underlying medical illnesses which are hypertriglyceridemia, hypertension and history of abdominal aortic aneurysm repair 13 years ago. On admission, his general condition was good but slightly dehydrated. His abdomen was soft but distended. There was no peritonitis. The rectum was empty on per rectal examination. The renal profile was deranged with urea of $9.7 \mathrm{mmol} / \mathrm{L}$, creatinine $137 \mathrm{mmol} / \mathrm{L}$. Other blood investigations were within normal limits. Serum lactate was 2.0. Venous blood gas showed no metabolic acidosis. His chest x-ray showed normal lung fields with no evidence of air under diaphragm (Figure 1a). Abdominal radiograph showed dilated large bowel with coffee bean sign (Figure 1b). 

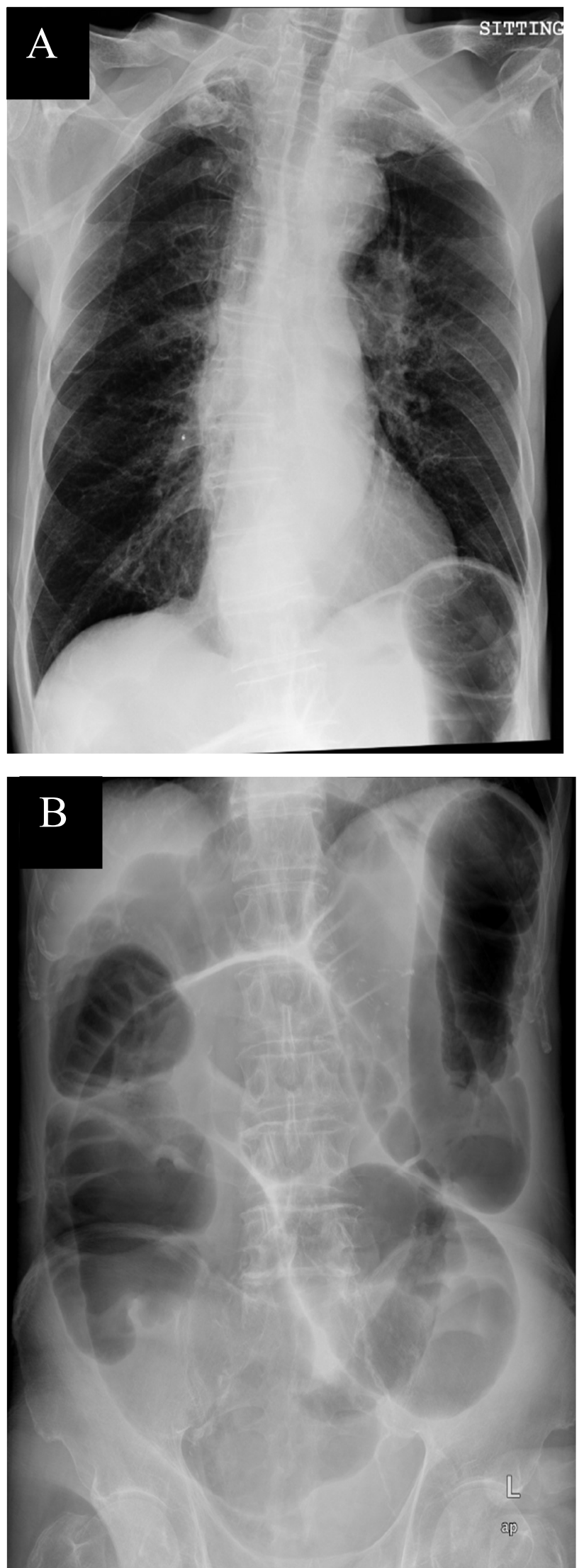

Figure 1(A). Erect chest radiograph upon admission showing no air under diaphragm. (B). Plain abdominal radiograph examination revealed dilated large bowel with severely dilated sigmoid loop with coffee bean sign.

He was given fluid resuscitation due to acute kidney injury. In view of stable sigmoid volvulus, he was immediately sent for flexible sigmoidoscopy and emergency endoscopic reduction was attempted. We managed to scope proximal to the twisted segment. Whirlpool sign was noted. The mucosa of sigmoid colon was healthy. A flatus tube was inserted and anchored. Post sigmoidoscopy, the patient was hemodynamically stable. In the ward, the flatus tube accidentally had dislodged.
It was reinserted with lignocaine gel using blinded method. The procedure was uneventful. He was stable until 6 hours post reinsertion, he started to deteriorate and developed tachycardia and type 1 respiratory failure. His ventilatory support was upgraded to ventilatory mask $40 \%$. On examination, his abdomen became tense and distended with mild tenderness on palpation. A computed tomography (CT) of abdomen was performed which revealed an extensive pneumoperitoneum suggesting of visceral perforation (Figure 2).

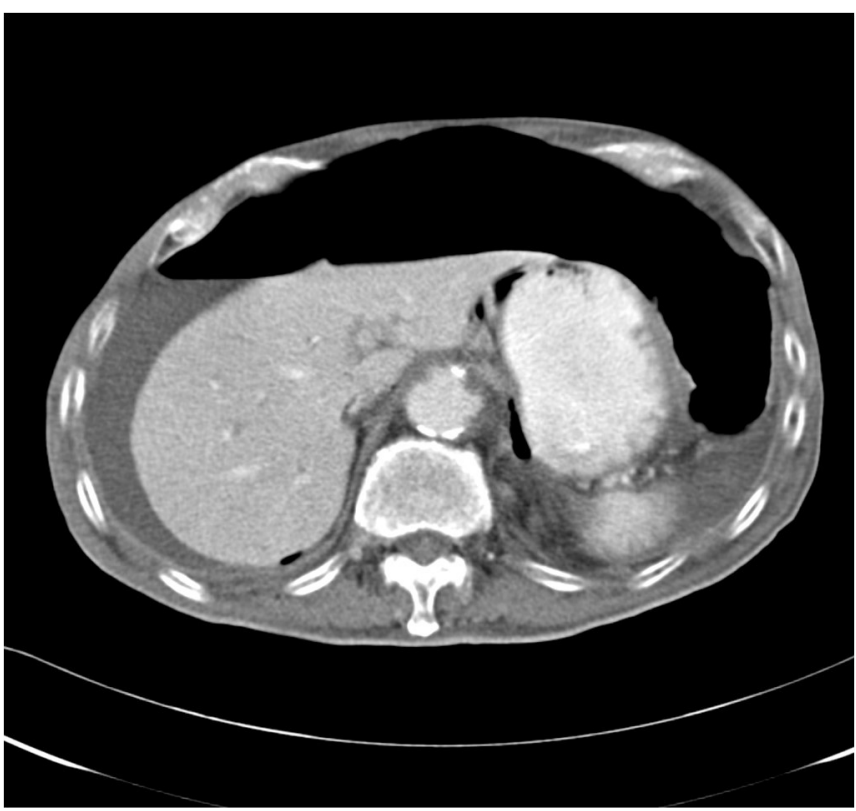

Figure 2. Plain abdominal computed tomography revealing gross pneumoperitoneum.

He was immediately posted for urgent exploratory laparotomy. Despite on fluid resuscitation, his condition even deteriorated. He started to have hypotension and type 2 respiratory failure requiring elective intubation. He was stabilized in the intensive care unit before embarking to surgery. Once stable, he was pushed to the operating theatre. During laparotomy, massive amount of faecal contamination was encountered upon entering the peritoneum. The sigmoid colon was redundant. A perforation was noted at the sigmoid colon with the tip of the sharp flatus tube abutting the colon (Figure 3a, 3b). Patient was preceded with Hartmann's procedure and peritoneal lavage.

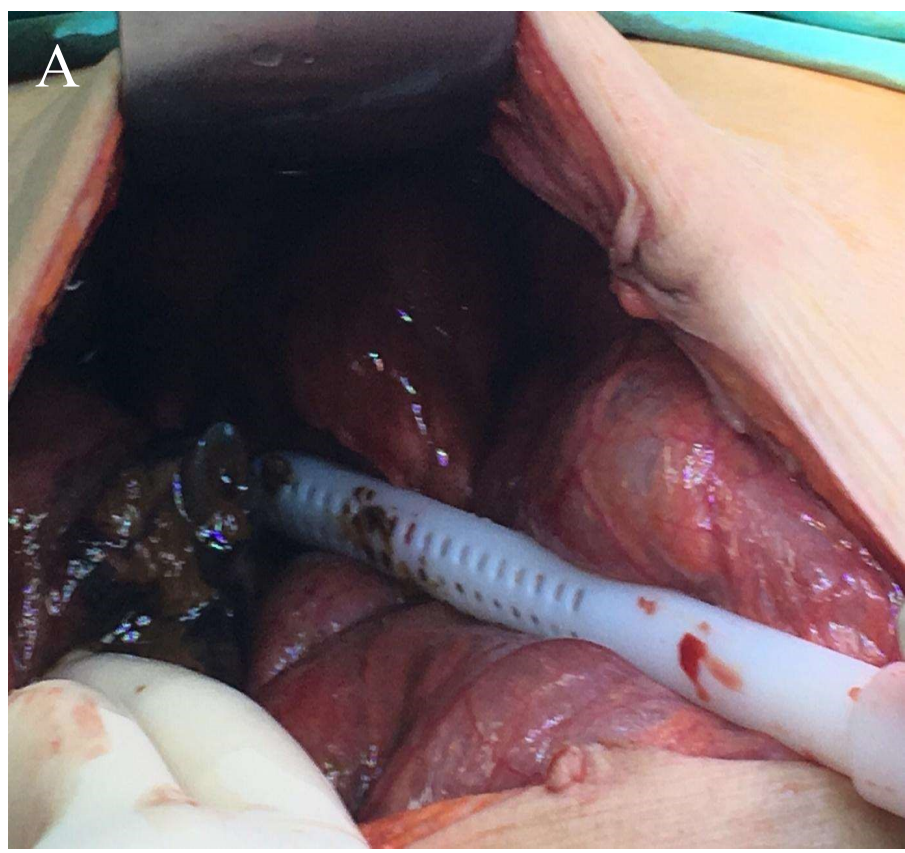

Figure 3(A). Tip of the sharp flatus tube piercing through the colon and causing perforation. 


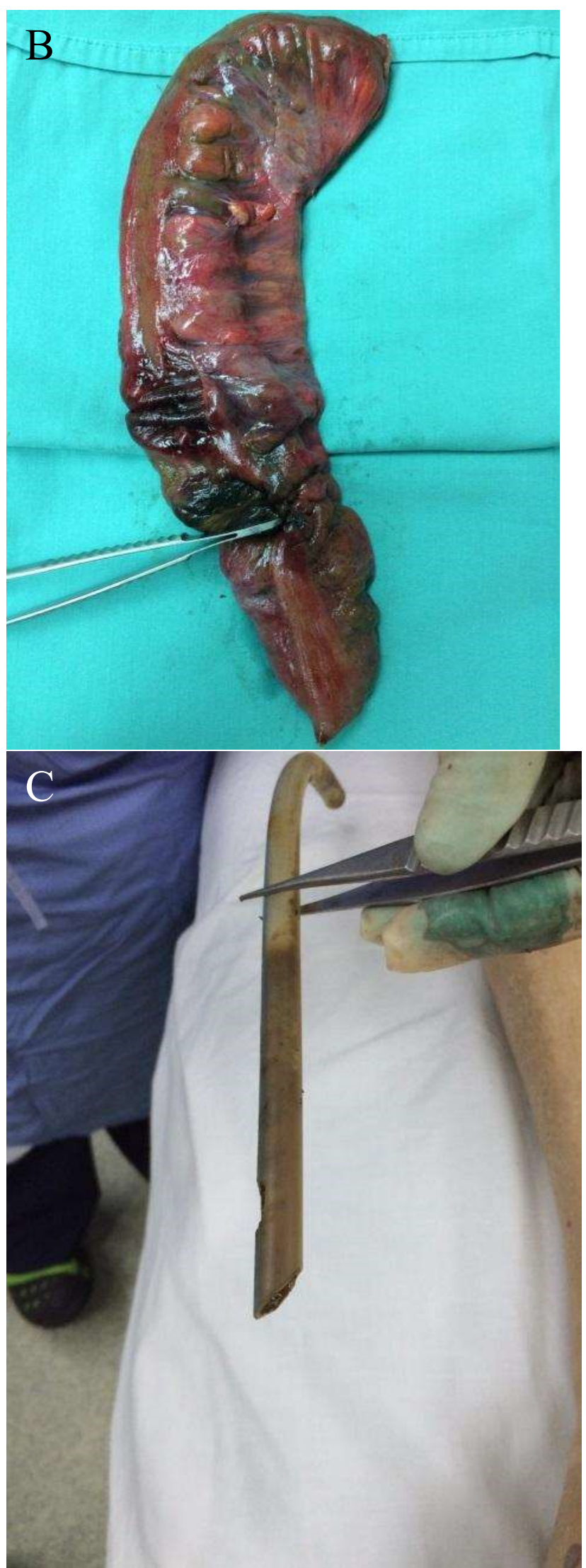

Figure 3 (B). Perforation noted at sigmoid colon as shown by the forceps. (C). A chest tube with sharp tip which was used as substitute for the soft flatus tube.

After the surgery, his general condition did not improve and he became critically ill. He developed disseminated intravascular coagulation, worsening metabolic acidosis and hypothermia. Despite on haemodialysis and inotropic support, he eventually succumbed after 3 days of surgery.

\section{DISCUSSION}

2019; 30: 212-214

Colonic volvulus is a common aetiology of large bowel obstruction. Majority of the cases happen in the sigmoid colon and followed by the caecum(1). Early diagnosis and prompt treatment are essential as volvulus without ischemia has mortality rate of less than $7 \%$ compared to the cases with ischemia which are $33-80 \%(1)$. The pathophysiology of sigmoid volvulus involves several factors. Three important factors are; elongated or redundant sigmoid loop, narrowed sigmoid mesocolon base at its parietal attachment and a torque force to the sigmoid loop, which causes the torsion process(5). Classically, sigmoid volvulus occurs in a clockwise direction. When the sigmoid colon twists on its mesenteric axis, it will cause closed loop obstruction as both ends are occluded. The bowel gas enters the closed loop but unable to escape from it, resulting in bowel dilatation and further tightening of the twisted loop, eventually compromising the blood supply to the bowel, causing bowel perforation and ischaemia(6).

The initial management in colonic volvulus is to exclude bowel ischemia. For acute uncomplicated non-ischaemic volvulus, the option of management is colonoscopic derotation, followed by elective definitive surgery(7). Ischaemic necrosis of sigmoid wall causing perforation is a common dreaded complication of sigmoid volvulus. During endoscopic detorsion and decompression of sigmoid volvulus, a drainage catheter is usually inserted into the sigmoid colon advances beyond the point of obstruction guided by a guide wire. If there is any sign of peritoneal irritation or ischemic bowel, peritonitis or unsuccessful non-surgical treatment, the only option of treatment is emergency surgical resection.

The flatus tube that was used in our case was not a proper soft flatus tube. It was a chest tube which was used as a substitution to the actual flatus tube. It was stiffer and accidentally had a sharp and pointed tip (Figure 3c). The initial flatus tube had dislodged post-endoscopic reduction and it was reinserted into the colon in a blinded technique with the sharp tip pointed into the colon. A high possible mechanism of iatrogenic mechanical perforation in this case was due to the direct force from the sharp tip of the flatus tube piercing through the wall of the sigmoid colon. During the endoscopic reduction, the colour of sigmoid colonic mucosa was visualized clearly, appeared healthy and viable. Thus, we did not suspect there was an ischemic perforation.

Endoscopic reduction of sigmoid volvulus certainly is a primary effective and safe emergency treatment of choice in uncomplicated acute sigmoid volvulus. latrogenic mechanical perforation of sigmoid colon post-endoscopic reduction of sigmoid volvulus is rare but it is absolutely important and life-threatening pitfall. Particularly the flatus tube that was used for reduction has a sharp tip end. In our case, the potential risk of mechanical perforation was high especially the flatus tube has a very sharp tip and it was reinserted not under the direct vision. Therefore, to prevent this hazardous complication, clinicians must ensure the flatus tube to be inserted under direct vision and extra precaution must be reminded in using flatus tube with sharp tip as it could cause mechanical perforation. A properly designed flatus tube should be used in this case. ${ }^{8}$ In our case, it was a lesson to learn to avoid similar calamity in the future.

In conclusion, iatrogenic sigmoid colon perforation after endoscopic perforation is a rare circumstance. It is a very important and life-threatening complication and should always be diagnosed early by acute care physicians. To avoid this dangerous complication, a proper soft flatus tube must be used in reduction of colon under direct endoscopic vision. Besides, acute care physician must learn to recognize pneumoperitoneum clinically to diagnose bowel perforation. An emergency operation has to be arranged as soon as patient's condition is optimized.

\section{Conflict of interest}

No conflict of interest was declared by the authors.

\section{REFERENCES}

1. Katsikogiannis N, Marchairiotis N, Zarogoulidis $P$, Sarika E, Stylianaki A, Zisoglou M et al. Management of sigmoid volvulus avoiding sigmoid resection. Case Rep Gastroenterol 2012; 6: 293-9.

2. Raveenthiran V. Observations on the pattern of vomiting and morbidity in patients with acute sigmoid volvulus. J Postgrad Med 2004; 50: 27-9.

3. Lal SK, Morgenstern R, Vinjirayer EP, Matin A. Sigmoid volvulus an update. Gastrointest Endosc Clin N Am 2006; 16: 175-87.

4. Lou Z, Yu ED, Zhang W, Meng RG, Hao LQ, Fu CG. Appropriate treatment of acute sigmoid volvulus in the emergency setting. World J Gastroenterol 2013;19:4979-83

5. Ward S, Khan D, Edwards T, Daniels I. Sigmoid volvulus: A new twist to an old problem. The Internet Journal of Surgery 2010; $27: 2$.

6. Tian L, Goh S. Sigmoid volvulus: Diagnostic twists and turns. Eur J Emerg Med 2006; 13 84-7.

7. Tsai MS, Lin MT, Chang KJ, Wang SM, Lee PH. Optimal interval from decompression to semi-elective operation in sigmoid volvulus. Hepatogastroenterology 2006; 53; 354-6.

8. Tang S, Wu R. Shou J. Endoscopic decompression, detorsion, and reduction of sigmoid volvulus. Video Journal and Encyclopedia of GI Endoscopy 2014; 2: 20-25. 